\title{
SENTIMENT ANALYSIS ON TWITTER OF PSBB EFFECT USING MACHINE LEARNING
}

\author{
Irwansyah Saputra ${ }^{1 *}$; Jose Andrean Halomoan ${ }^{2}$; Adam Bagusmugi Raharjo ${ }^{3}$; \\ Cyra Rezky Ananda Syavira ${ }^{4}$ \\ Sistem Informasi \\ STMIK Nusa Mandiri \\ www.nusamandiri.ac.id \\ irwansyah.iys@nusamandiri.ac.id 1*; 11190569@nusamandiri.ac.id 2; 1110698@nusamandiri.ac.id ${ }^{3}$; \\ 11190570@nusamandiri.ac.id ${ }^{4}$ \\ (*) Corresponding Author
}

\begin{abstract}
A collection of tweets from Twitter users about PSBB can be used as sentiment analysis. The data obtained is processed using data mining techniques (data mining), in which there is a process of mining the text, tokenize, transformation, classification, stem, etc. Then calculated into three different algorithms to be compared, the algorithm used is the Decision Tree, K-NN, and Naïve Bayes Classifier to find the best accuracy. Rapidminer application is also used to facilitate writers in processing data. The highest results from this study were the Decision Tree algorithm with an accuracy of $83.3 \%$, precision $79 \%$, and recall $87.17 \%$.
\end{abstract}

Keywords: Twitter; Data Mining; Sentiment Analysis; Decision Tree Algorithm; K-NN; Naïve Bayes Classifier

\begin{abstract}
Abstrak-Kumpulan tweet dari pengguna Twitter mengenai PSBB dapat dimanfaatkan menjadi sebuah analisa sentimen. Data yang diperoleh diolah menggunakan teknik penambangan data (data mining), didalamnya terdapat proses penambangan teks, tokenize, transformasi, klasifikasi, stem, dll. Kemudian dikalkulasikan kedalam tiga algoritma yang berbeda untuk dibandingkan, algoritma yang digunakan yaitu Decision Tree, K-NN, dan Naïve Bayes Classifier dengan tujuan menemukan akurasi terbaik. Aplikasi Rapidminer juga digunakan untuk mempermudah penulis dalam mengolah data. Hasil tertinggi dari penelitian ini adalah algoritma Decision Tree dengan accuracy 83,3\%, precision $79 \%$ dan recall $87,17 \%$.
\end{abstract}

Kata Kunci: Twitter; Data Mining; Analisis Sentimen; Algoritma Decision Tree; K-NN; Nä̈ve Bayes Classifier

\section{INTRODUCTION}

COVID-19 Being the center of attention in early 2020, not only in Indonesia, but several countries are also experiencing the same problem due to this virus.

In inhibiting the rate of spread of the COVID19 virus, several countries use different methods, from strict ones such as in China and Italy with LockDown, or in Indonesian laws and regulations known as regional quarantine, to social restrictions such as in Taiwan. (Handayanto \& Herlawati, 2020)

Apart from consuming many victims, many activities were stopped due to the PSBB, such as many workers who were sent home, restricted activities, and many others.

All information or news about COVID-19 and PSBB is always updated in news newspapers and television media, in addition to newspapers and TV media, social media also participates in providing information about COVID-19 and PSBB such as Facebook, Instagram, Twitter, etc.

The problem that occurs in this research is that there is too much data so that the author cannot quickly and accurately distinguish the positive or negative opinions of Twitter users about PSBB. because of that, the author feels the need to analyze the sentiment on Twitter about PSBB.

In solving the problem, the author uses the Machine learning method to classify the opinion of Twitter users about PSBB. This study classifies the sentiments of Twitter users 'opinions about PSBB and determines whether Twitter users' opinions about PSBB have positive or negative sentiments. Features that differ from what Twitter users think of PSBB are extracted with the Naïve Bayes Classifier (NBC), Decision Tree, and K-Nearest Neighbor (K-NN) machine learning algorithms to produce the best results. Then compare the results of the three algorithms to find out which classifier gives the best results in terms of accuracy, precision, and recall. This study obtained $80.03 \%$ accuracy for the Naïve Bayes Classifier (NBC), 83.3 accuracies for the Decision Tree, and $80.80 \%$ accuracy for K-Nearest Neighbor (K-NN) in the use of bigram. 
On the other hand, information mining is the way toward searching for fascinating examples or data with regards to chosen information utilizing certain strategies or techniques. Information mining strategies, techniques, or calculations change generally (Muzakir \& Wulandari, 2016). Thus data mining can be used as a sentiment analysis because it can process large amounts of tweet data.

Sentiment analysis or commonly referred to as opinion mining is a process of finding user opinions about several topics or texts submitted by users. In another sense, a process to determine whether a piece of writing is positive, negative, or neutral. (Muljono et al., 2018)

The purpose of this study is to determine the positive and negative sentiments as well as input and criticism from the social media user community, especially Twitter, on the implementation of the PSBB to make it easier for data users to rethink the PSBB policy that is enforced.

\section{MATERIALS AND METHODS}

Research on analytical sentiment from tweets on Twitter about the implementation of PSBB in Indonesia in preventing the spread of the COVID-19 virus. Sentiment analysis is carried out to see opinions or opinions on a problem or object by someone, whether they tend to have negative or positive opinions (Buntoro et al., 2014). What the authors present is evidence that there has been previous research on the analysis of sentiment from the use of social media Twitter.

Supposition investigation from Twitter should zero in on grouping issues. The arrangement is the way toward finding a lot of models (works) that can depict and separate information classes or ideas, to have the option to utilize the model to anticipate the class of an article whose class isn't yet known (Rani, 2015). Different grouping approaches, for example, Naïve Bayes, Decision Tree, and K-Nearest Neighbor (K-NN) have been applied to locate the best outcomes.

Consequently, digging can be utilized for a degree of feeling investigation. Information mining is the way toward discovering examples or information. Examples must be legitimate, helpful, and reasonable in a few stages: pre-preparing, information mining, and post-handling. In examining assumption, a few stages should be done to get the best test outcomes. The means comprise of information assortment and naming, prehandling, and Sentiment examination, Figure 1 shows the means in the proposed investigation notion characterization.

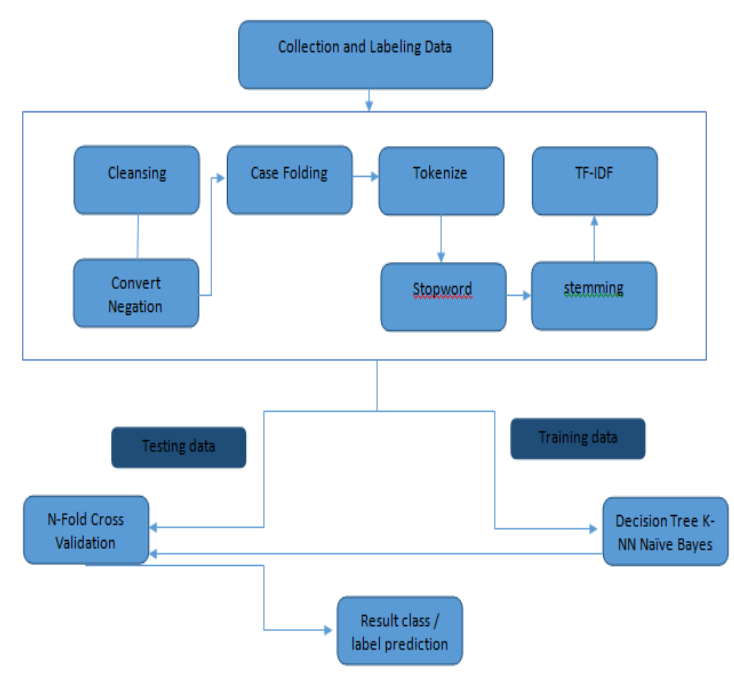

Figure 1. Diagram of the Classification System for Sentiment Analysis

\section{A. Data Collection and Labeling}

The first stage in conducting the sentiment analysis process is data collection. Data retrieved from Twitter with a search query on PSBB Securities totaling 170 records using the Rapidminer application.

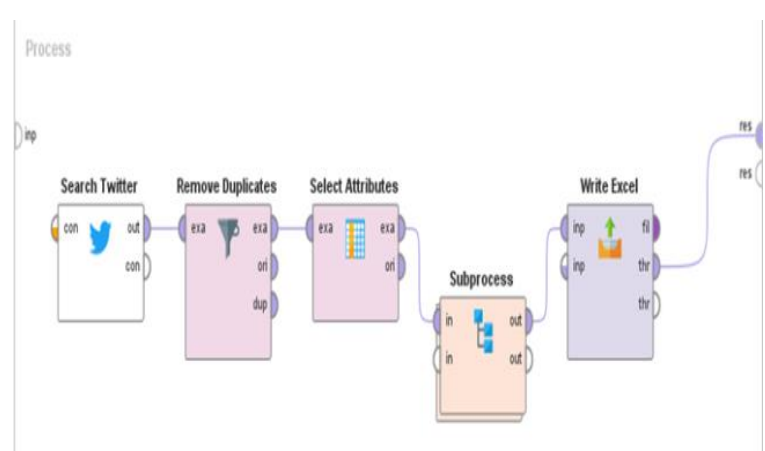

Figure 2. Retrieval of data from Twitter

Figure 2 shows retrieving information from Twitter utilizing "Search Twitter" content and putting away the information in a dominant record utilizing "Compose Excel" content by just separating the content from the tweet and erasing all copy tweets with "Eliminate Duplicates" content. The subsequent stage is to mark it. led to partition the information into a few assessment classes that will be utilized. The quantity of opinion classes utilized is two classes, to be specific negative and positive. The reason for this marking cycle is to separate the dataset into 2 sections, to become preparing information and testing information. information is utilized to prepare the framework so it can perceive the example you are searching for, while testing information is the information used to test the aftereffects of the 
preparation that has been done. Coming up next is a case of a dataset that has been marked:

Table 1. Examples of Dataset Labels

\begin{tabular}{ll}
\hline Text & Sentiment \\
\hline Efek psbb jadi sering bangun pagi & POSITIVE \\
\hline Tahukan kamu, bahwa sekrng 22 April & \\
2020 adalah hari bumi, dan dg adanya & POSITIVE \\
pandemi ini saya rasa bumi yg lagi & \\
tersenyum krna dia tdk terkena Polusi & \\
udara(penyehatan), efek dari Lockdown & \\
PSBB dan \#dirumahaja & \\
\hline $\begin{array}{l}\text { Aduh padat merayap gini efek psbb } \\
\text { wasalam telat deh ?? }\end{array}$ & \\
\hline $\begin{array}{l}\text { Ini efek PSBB, banyaknya pengangguran } \\
\text { apa karna napi yg dibebasin?! }\end{array}$ & NEGATIVE \\
\hline
\end{tabular}

\section{B. Pre-Processing}

After the information is named, the subsequent stage is pre-handling. This stage is where the information is set up to become information that is fit to be investigated. There are a few phrases in this preprocessing, including purifying, convert refutation, case collapsing, tokenization, separating stop words, and stemming in Indonesian. Figure 3 shows the "Subprocess" administrator. For this situation utilizing the content "Remove URL", "Convert Negation".

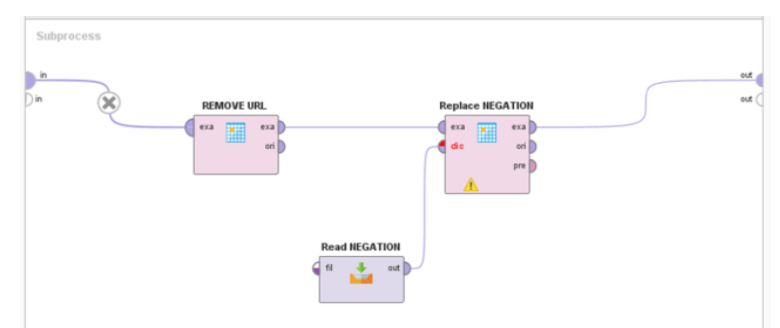

Figure 3. Subprocess Operators

Figure 4 shows the "Process Document" operator, using the contents of "Transform Cases", "Tokenize", "Stopword Filter" and "Stem" in Indonesian.

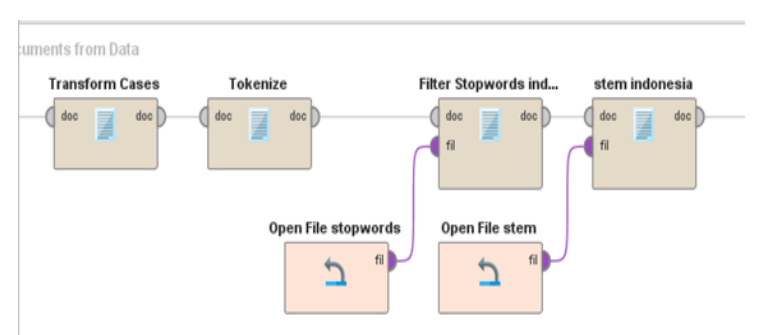

Figure 4. Contents Operator Process Document

Coming up next is a nitty-gritty portrayal of the above pre-preparing stages:

1. Cleansing

This stage of the process is a process to clean up unnecessary attributes in data input such as symbols and punctuation marks (Amalia et al., 2019). Work to decrease the commotion in the dataset. Instances of discarded characters, for example, URLs, labels (\#), accentuation checks, for example, periods (.), Commas (.), and other accentuation marks. This is a case of an information cleaning sentence, the info "The effect of direct lockdown loss of trillions https://t.co/K6uMYZG5vc", the output of "The effect of direct lockdown loss of trillions".

2. Convert Negation

Convert negation, which is the process of changing the negation word abbreviation contained in the status data into a complete negation word. (Jayanti et al., 2016) This is a case of a sentence change refutation, input "PSBB effect feels direct trillions loss", output "psbb effect think lockdown immediately lost trillions ".

3. Case Folding

In writing tweets, there are usually different letterforms, case folding is a process in text preprocessing that is carried out to uniform the characters in the data. (Jumeilah, 2017) This is a case of case collapsing, input "PSBB effect feels direct lockdown trillions loss", becomes output "psbb effect feeling lockdown direct trillions loss".

4. Tokenization

Tokenization is the process of dividing input text into small units called tokens. Tokens or terms commonly referred to can be in the form of words, numbers, or punctuation marks. In this study, punctuation is removed so that it is not considered a token. (Roji \& Irhamah, 2019) This is a case of a tokenization sentence, input "psbb effect, sense of direct lockdown, trillions loss", output "effect, psbb, feeling, lockdown, direct, loss, trillions ".

5. Filtering

Separating is the phase of disposing of words that show up in huge numbers however are esteemed to have no importance (stopwords). A stopword list is a lot of words that are broadly utilized in numerous dialects. The purpose behind eliminating words identified with text mining is a direct result of their too broad use so clients can zero in on different words that are substantially more significant. This is a case of a stopword sentence, the input "psbb effect, direct lockdown loss trillions", the output "direct psbb effect trillions loss". case of a word from Stopwords:

Table 3. Examples of Stopwords

\begin{tabular}{ccccc}
\hline rasa & lockdown & kalau & pada & yaitu \\
\hline aku & dia & kami & saja & asik \\
\hline bapak & ini & lalu & hai & hari \\
\hline berbagai & itu & lewat & untuk & masa \\
\hline Cara & jadi & meski & yang & tapi \\
\hline Cuma & juga & oleh & wah & hal \\
\hline
\end{tabular}




\section{Stemming}

Stemming is the way toward planning and unraveling the different structures (variations) of a word into its essential word structure. The stemming calculation is developed based on Indonesian morphological rules which classify prefixes into prefixes, infixes, suffixes, and confixes. This algorithm uses a basic word dictionary and supports recoding, namely the rearrangement of words that have undergone an excess stemming process (Jarob, Y., Sujaini, H., \& Safriadi, 2016). This is an example of a sentence, the input "direct lockdown effect trillions loss", and the output "direct lockdown loss trillions effect". The following is an example of a word stemming:

Table 4. Examples of Word Stemming

\begin{tabular}{cc}
\hline Sebelum & Sesudah \\
\hline trilliunan & triliun \\
\hline serendah & rendah \\
\hline sebelum & belum \\
\hline diberikan & beri \\
\hline secukupnya & cukup \\
\hline dilaksanakan & laksanakan \\
\hline
\end{tabular}

\section{Weighting Word}

Word weighting is a mechanism to score the occurrence of words in a text document and to calculate them, you can use Eq.(Rasenda, 2020)

$t f-i d f_{t . d}=t f_{d} * i d f_{t}$

The term recurrence (tf) is the recurrence at which the term ( $t$ ) shows up in the record (d). One mainstream strategy for gauging words is the TFIDF as per the TF-IDF technique. (Nurjannah et al., 2016) This technique consolidates two ideas for weight count, specifically the recurrence of event of a word in a specific archive and the backwards recurrence of reports containing that word. The recurrence with which the word shows up in a given record shows how significant it is in the archive. The occasions a record contains this word demonstrates how basic it is. So the heaviness of the connection between a word and a record will be high if the recurrence of the word is high in the report and the recurrence of the entire archive containing that word is low in the archive. Meanwhile, Archive Frequency is the quantity of records where the term shows up. The more modest the recurrence of event, the more modest the worth. While ascertaining the recurrence of terms, all the words in them are viewed as significant. Notwithstanding, a few words are less significant and don't should be considered, for example, "at-", "back", "and", and so forth In this way, these less significant words should be diminished and included with other significant words. This is the fundamental thought of why a stopword is required., the score can be obtained using Eq. The TF-ID method determines the relative frequency of words in a particular document via an inverse proportion of words over the entire document (Trstenjak et al., 2014).

\section{Classification of Sentiment Analysis}

After pre-preparing the information, the following stage is the notion investigation order. This stage is the stage for giving preparing and executing different information mining calculations. Figure 5 shows the substance of the administrator "Cross-Validation" in the Rapidminer application. For this situation, it utilizes three distinctive order administrators for examination, specifically the Decision Tree arrangement administrator, the K-NN characterization administrator, and the Naïve Bayes grouping administrator.

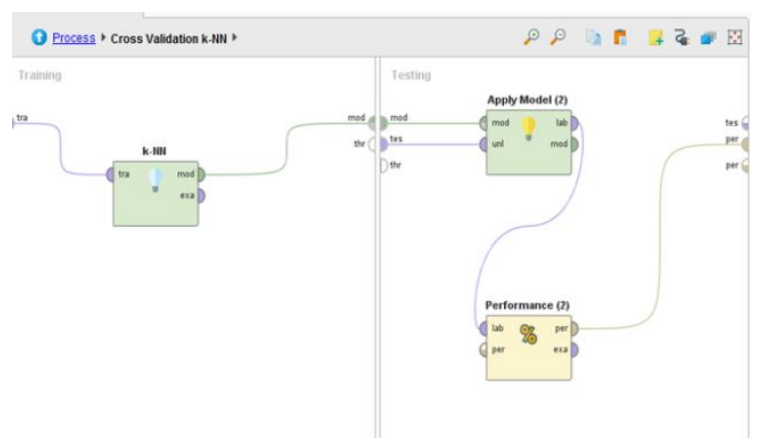

Figure 5. Cross-Validation Operator

\section{Evaluation of Sentiment Analysis}

After this testing cycle has been finished, one more advance is expected to decide the nature of the cycle that has been done, to be specific the assessment of the outcomes. At this stage, the presentation of the counts that have been done will be tried with two boundaries, to be specific exactness, accuracy, and review (Manning et al., 2009), (Feldman \& Sanger, 2007), (Prameswari \& Setiawan, 2019).

Accuracy (A) is the quantity of reports grouped effectively, either True Positive or True Negative. Ascertaining the exactness worth can utilize the condition:

$A=\frac{(T P+T N)}{(T P+T N+F P+F N)} * 100 \%$

Precision (P) is how much the handling result is applicable to the data you need to discover. As such, accuracy is a True Positive order and all information is anticipated as a positive class. Ascertaining the estimation of exactness can utilize the condition: 
$P=\frac{T P}{F P+T P} x 100 \%$

Recall (R) is how much the dealing with result is material to the information you have to find. With everything taken into account, precision is a True Positive gathering and all data is foreseen as a positive class. Calculating the assessment of precision can use the condition:

$R=\frac{T P}{T P+F N} \times 100 \%$

Variables like TN, TP, FN, and FP originate from the disarray lattice. TN represents True Negative, negative information that is named negative. TP represents True Positive, positive information is named positive. FN represents False Negative, positive information is named negative. FP represents False Positive, negative information is delegated positive (Hadna et al., 2016). For a more point by point clarification:

Table 5. Confusion Matrix

\begin{tabular}{ccc}
\hline & Prediction Yes & Prediction No \\
\hline True Yes & $T P$ & $F N$ \\
\hline True No & $F P$ & $T N$ \\
\hline
\end{tabular}

After the information is gathered, the information will be isolated into preparing information and testing information. Information sharing will be finished utilizing the $\mathrm{N}$-crease cross-approval technique to dispense with word predisposition. $\mathrm{N}$ crease cross-approval partitions the report into $n$ parts. In a progression of trials, $n$ bits of record arrangement analyses will be completed with each test utilizing one section as testing information, (n$1) / 2$ sections as marked archives, and (n-1)/2 different parts as reports without names that will be traded without fail. explore $n$ times. The previously set of reports claimed is arbitrarily arranged before being embedded into the crease. This is done to abstain from gathering reports from one specific class in the overlay.

\section{RESULTS AND DISCUSSION}

This part depicts the aftereffects of the test and breaks down its exhibition.
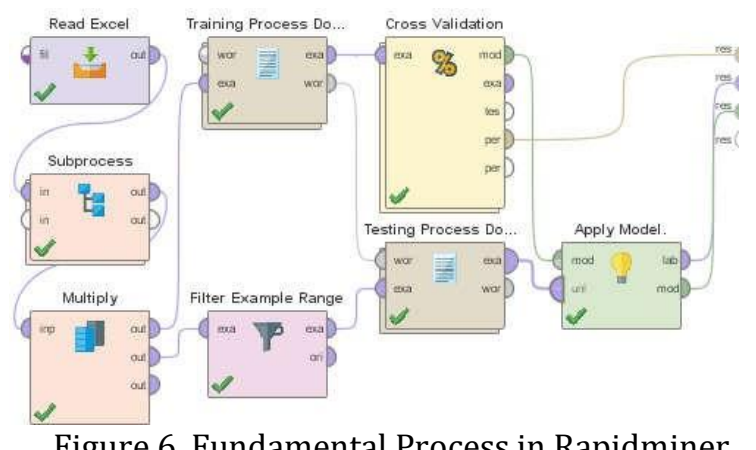

Figure 6. Fundamental Process in Rapidminer

Figure 6 shows the fundamental cycle in the Rapidminer application. "Peruse Excel" content is utilized to peruse information in an Excel record. "Subprocess" and "Cycle Document" content are utilized for pre-handling. Content "CrossValidation" is utilized for arrangement and assessment of assumption investigation with tests performed multiple times (10-overlay Cross Validation).

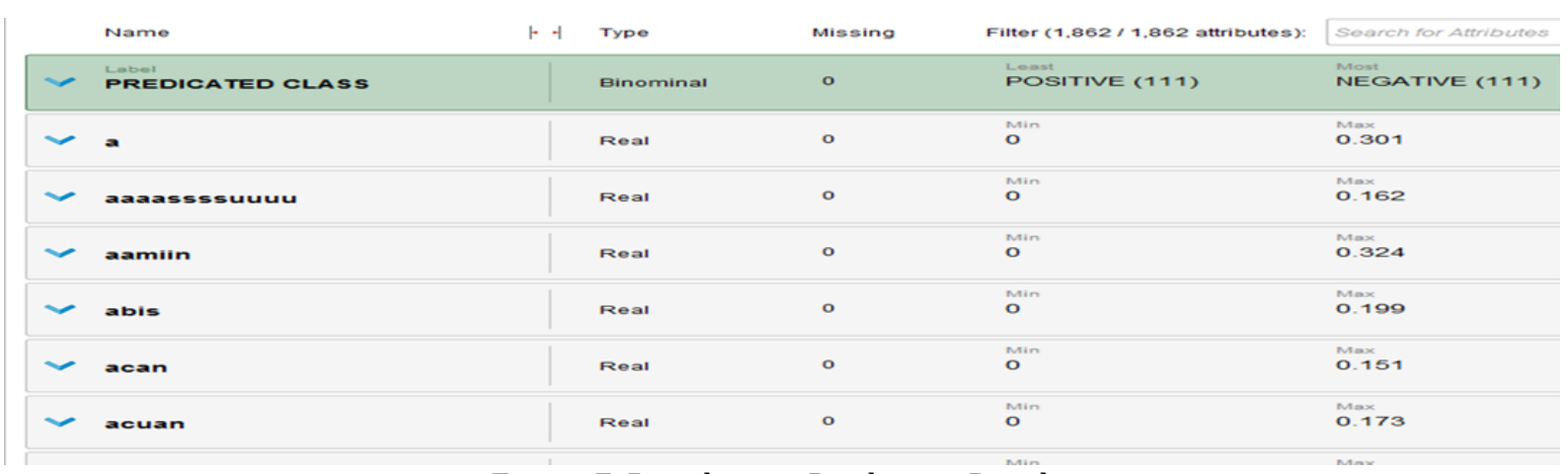

Figure 7. Rapidminer Prediction Results

Figure 7 shows the forecast outcomes in the Rapidminer application. Take a gander at the opinion and a similar expectation name with the assessment mark. Coming up next is an outline of the aftereffects of the disarray network from every calculation in Rapidminer: 
Table 5. Confusion Matrix for Each Algorithm

\begin{tabular}{lllll}
\hline Method & $T P$ & $F P$ & $T N$ & $F N$ \\
\hline Decision Tree & 34 & 9 & 36 & 5 \\
\hline K-NN & 32 & 8 & 48 & 11 \\
\hline Naïve Bayes & 37 & 6 & 47 & 22 \\
\hline
\end{tabular}

From the disarray lattice in table 6, the normal exactness, accuracy, and review esteems are shown by computations utilizing the recipe (8), (9), (10).

Table 6. Estimation of Accuracy, Precision, and Recall Using Formula

\begin{tabular}{llll}
\multicolumn{4}{c}{ Recall Using Formula } \\
\hline Method & Accuracy & Precision & Recall \\
\hline Decision Tree & $83,3 \%$ & $79 \%$ & $87,17 \%$ \\
\hline K-NN & $80,80 \%$ & $80 \%$ & $74,41 \%$ \\
\hline Naïve Bayes & $80,03 \%$ & $86 \%$ & $62,71 \%$ \\
\hline
\end{tabular}

There are contrasts in the consequences of normal exactness esteems utilizing the Rapidminer application as appeared in table 7 underneath:

Table 7. Estimation of Accuracy, Precision, and Recall Using Rapidminer

\begin{tabular}{llll}
\hline Method & Accuracy & Precision & Recall \\
\hline Decision Tree & $83,3 \%$ & $79 \%$ & $87,17 \%$ \\
\hline K-NN & $80,80 \%$ & $80 \%$ & $74,41 \%$ \\
\hline Naïve Bayes & $80,03 \%$ & $86 \%$ & $62,71 \%$ \\
\hline
\end{tabular}

Table 7 shows the results that the algorithm that has the highest accuracy is the Decision Tree with a percentage of $83.3 \%$. Accuracy indicates the accuracy between the predictions generated by the model and the original sentiment values in the dataset. The higher the percentage of accuracy, the higher the accuracy of the model in predicting the true value. Exactness portrays the degree of precision between the mentioned information and the prescient outcomes given by the model. Precision answers the question "What percentage of positive correct sentences of the whole sentence are predicted to be positive?". Meanwhile, Recall describes the success of the model in rediscovering information. Recall answers the question "What percentage of sentences that are predicted to be positive compared to the whole sentence are actually positive?".

In this case, the model created can provide good result accuracy. However, because the Covid-19 case has not ended yet, tweets related to PSBB will always appear on Twitter and analysis may change due to uncertain conditions.

\section{CONCLUSION}

In this examination, an endeavor was made to group the investigative slant of tweets on Twitter about the impacts of PSBB on society in Indonesia.
To sum up the perspective on this general public, text mining procedures are utilized, and information mining utilizes three unique calculations, specifically Decision Tree, K-NN, and Naïve Bayes. Three calculations foresee names on the dataset. The outcomes show the exactness of the Decision Tree, KNN, and Naïve Bayes at $83.3 \%$, $80.80 \%$, and $80.03 \%$. The outcomes for the accuracy of the Decision Tree, K-NN, and Naïve Bayes are $81.06 \%, 82.72 \%$, and $87.54 \%$. Then, the outcomes for review from the Decision Tree, K-NN, and Naïve Bayes were $87.17 \%, 74.41 \%$, and $62.71 \%$. Along these lines, it very well may be presumed that the Decision Tree calculation is the best classifier to use in computations utilizing online media datasets on the grounds that it gives more exact and exact forecasts Because this sentiment analysis is a momentum, where the data are taken is data from a case that occurred during the COVID-19 pandemic, this analysis may change its outlook because conditions cannot be confirmed, so the suggestion is to update the public sentiment on regulations. PSBB.

\section{REFERENCE}

Amalia, A., Gunawan, D., Fithri, Y., \& Aulia, I. (2019). Automated Bahasa Indonesia essay evaluation with latent semantic analysis. Journal of Physics: Conference Series, 1235(1). https://doi.org/10.1088/1742$6596 / 1235 / 1 / 012100$

Buntoro, G. A., Adji, T. B., \& Purnamasari, A. E. (2014). Sentiment Analysis Twitter dengan Kombinasi Lexicon Based dan Double Propagation. Citee, 39-43.

Feldman, R., \& Sanger, J. (2007). The Text Mining Handbook: Advanced Approaches in Analyzing Unstructured Data. Cambridge University Press.

Hadna, M. S., Santosa, P. I., \& Winarno, W. W. (2016). Studi Literatur Tentang Perbandingan Metode Untuk Proses Analisis Sentimen Di Twitter. Seminar Nasional Teknologi Informasi Dan Komunikasi, 2016(Sentika), 57-64.

Handayanto, R. T., \& Herlawati, H. (2020). Efektifitas Pembatasan Sosial Berskala Besar (PSBB) di Kota Bekasi Dalam Mengatasi COVID-19 dengan Model SusceptibleInfected-Recovered (SIR). Jurnal Kajian Ilmiah, 20(2), 119-124. http://ejurnal.ubharajaya.ac.id/index.php/JK I/article/view/119 
Jarob, Y., Sujaini, H., \& Safriadi, N. (2016). Uji Akurasi Penerjemahan Bahasa Indonesia Dayak Taman Dengan Penandaan Kata Dasar Dan Imbuhan. Jurnal Edukasi Dan Penelitian Informatika (JEPIN), 2(2), 78-83.

Jayanti, L., Sentinuwo, S. R., Lantang, O. A., \& Jacobus, A. (2016). Analisa Pola Penyalahgunaan Facebook Sebagai Alat Kejahatan Trafficking Menggunakan Data Mining. Jurnal Teknik Informatika, 8(1). https://doi.org/10.35793/jti.8.1.2016.12231

Jumeilah, F. S. (2017). Penerapan Support Vector Machine (SVM) untuk Pengkategorian Penelitian. Jurnal RESTI (Rekayasa Sistem Dan Teknologi Informasi), 1(1), 19. https://doi.org/10.29207/resti.v1i1.11

Manning, C. D., Raghavan, P., \& Schütze, H. (2009). Introduction to Information Retrieval (Illustrate). Cambridge University Press.

Muljono, M., Artanti, D. P., Syukur, A., Prihandono, A., \& Setiadi, D. R. I. M. (2018). Analisa Sentimen Untuk Penilaian Pelayanan Situs Belanja Online Menggunakan Algoritma Naïve Bayes. Konferensi Nasional Sistem Informasi (KNSI) 2018, 165-170 http://jurnal.atmaluhur.ac.id/index.php/knsi 2018/article/view/353

Muzakir, A., \& Wulandari, R. A. (2016). Model Data Mining sebagai Prediksi Penyakit Hipertensi Kehamilan dengan Teknik Decision Tree. Scientific Journal of Informatics, 3(1), 19-26. https://doi.org/10.15294/sji.v3i1.4610

Nurjannah, M., Hamdani, H., \& Astuti, I. F. (2016). Penerapan Algoritma Term FrequencyInverse Document Frequency (TF-IDF) untuk Text Mining. Informatika Mulawarman: Jurnal Ilmiah Ilmu Komputer, 8(3), 110-113. http://e-

journals.unmul.ac.id/index.php/JIM/article/v iew/113

Prameswari, K., \& Setiawan, E. B. (2019). Analisis Kepribadian Melalui Twitter Menggunakan Metode Logistic Regression dengan Pembobotan TF-IDF dan AHP. E-Proceeding of Engineering, 6(2), 9667-9682. https://libraryeproceeding.telkomuniversity. ac.id/index.php/engineering/article/view/1 0702

Rasenda. (2020). Implementasi K-NN Dalam Analisa Sentimen Riba Pada Bunga Bank
Berdasarkan Data Twitter. Jurnal Informatika, 7(April), 1-8. https://doi.org/10.30865/mib.v4i2.2051

Roji, M. F. F., \& Irhamah, I. (2019). Topic Discovery pada Dokumen Abstrak Jurnal Penelitian di Science Direct Menggunakan Association Rule. Inferensi, 2(2), 97. https://doi.org/10.12962/j27213862.v2i2.6 824

Trstenjak, B., Mikac, S., \& Donko, D. (2014). KNN with TF-IDF based framework for text categorization. Procedia Engineering, 69, 1356-1364. https://doi.org/10.1016/j.proeng.2014.03.12 9 
